\title{
New algorithm for the diagnosis of hereditary dystonia
}

\author{
Novo algoritmo para o diagnóstico de distonias hereditárias \\ Sarah Camargos, Francisco Cardoso
}

\begin{abstract}
Taking into account the crescent interest in the field of dystonia genetics, we have organized a didactic and fast algorithm to diagnose the main forms of hereditary dystonias. The key branch of this algorithm is pointed to dystonia classification in primary, plus, or paroxysmal. The specific characteristics of each syndrome will reveal the diagnosis.
\end{abstract}

Key words: dystonia, Parkinsonism, algorithm.

\section{RESUMO}

Levando em consideração o interesse crescente no campo da genética das distonias, organizou-se um algoritmo rápido e didático com a finalidade de auxiliar no diagnóstico das principais formas de distonia hereditária. O ramo principal desse algoritmo é a própria classificação da distonia: primária, paroxística, ou plus. As características específicas de cada síndrome podem sugerir o diagnóstico.

Palavras-Chave: distonia, parkinsonismo, algoritmo.

Dystonias are the third more common movement disorder after tremor and Parkinsonism. Its prevalence is around two up 50 cases per million (early onset, defined as the onset under 20 years-old) and 30 up to 7,320 cases per million in late onset (defined as the onset over 20 years-old) ${ }^{1}$. In relation to the etiologic classification, dystonia can be primary or secondary. It is called primary when the only clinical presentation is dystonia, and there are no structural changes or inborn errors of metabolism. It is called secondary when dystonia follows a neurological inherited disorder or an exogenous insult and is usually associated with other abnormalities, such as Parkinsonism, dementia, pyramidal, or cerebellar signs ${ }^{2}$. Secondary dystonias are classified into: due to an exogenous or environmental, other known causes and related to another movement disorder or associated with a hereditary neurological disease. When associated with an hereditary neurological disease, it can be subclassified as dystonia plus which is accompanied of other signs other than dystonia without evidence of neurodegeneration or neurodegenerative dystonia.

We have proposed, with this new algorithm, to elucidate the diagnosis of hereditary dystonias (Figure).

The very first question to be answered is whether the supposed hereditary dystonia is primary, plus, or paroxysmal.

\section{PRIMARY DYSTONIA}

If dystonia is primary, one should consider the age at onset and dystonia spread pattern and check if there is involvement of the cranial and laryngeal muscles.

The most common hereditary dystonia is DYT1. It has a childhood or adolescent onset usually beginning in one limb, spreading to other limbs and to axial muscles, and it becomes generalized but typically it spares laryngeal and cranial muscles $^{3}$. Although DYT6 is phenotypically similar to DYT1, a great proportion of DYT6 cases have their onset in cranial or cervical muscles, and those who present limb symptoms, later they may develop cranial or cervical dystonia. Most of patients have involvement of the laryngeal muscles ${ }^{4}$. Genetic testing is available for both conditions. Therefore, if there is primary dystonia with involvement of cranial and laryngeal muscles, one probability of test is DYT6, if there is not, one can use DYT1. Isolated craniocervical dystonia with or without involvement of speech could be secondary to DYT4 or 7, respectively ${ }^{5-6}$, however both are rare. Other primary dystonias described are DYT2, 13 and 17, all of them overlapping DYT1 and 6. Unfortunately, genes have not been yet identified for those conditions. Although only DYT2 and 17 have an

MD,PhD; Movement Disorder Clinic, Hospital das Clínicas, Departamento de Clínica Médica, Faculdade de Medicina da Universidade Federal de Minas Gerais (UFMG), Belo Horizonte MG, Brazil.

Correspondence: Sarah Camargos; Rua Grão Para 85/506; 30150-340 Belo Horizonte MG - Brazil; E-mail: sarahcamargos@terra.com.br

Support: Sarah Camargos received grant from Roche.

Conflict of interest: There is no conflict of interest to declare.

Received 29 April 2012; Received in final form 17 May 2012; Accepted 30 May 2012 


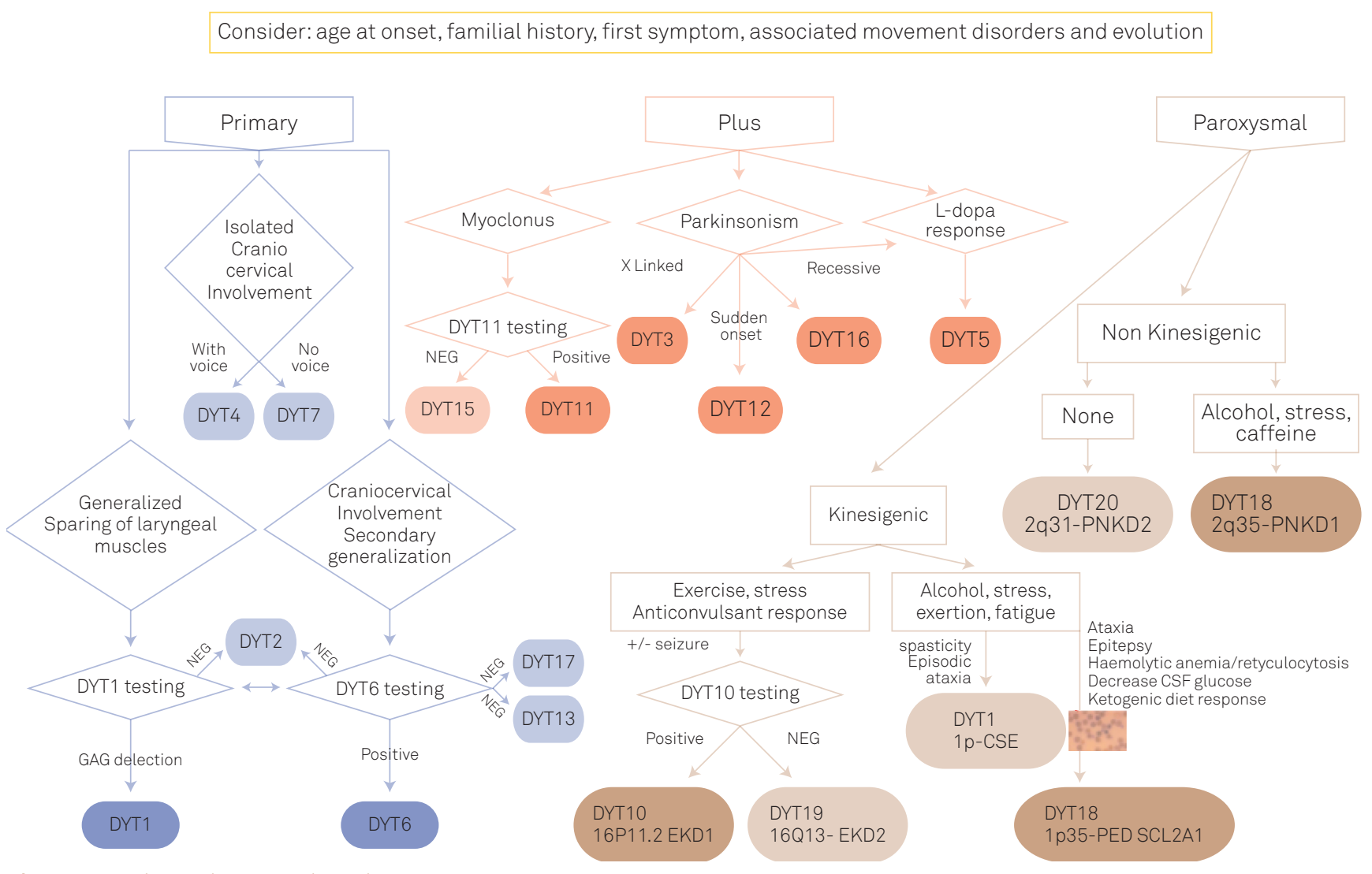

Figure. Hereditary dystonia algorithm.

autosomal recessive mode of transmission, DYT1 and DYT6 have an incomplete penetrance (30 and $60 \%$, respectively), which can be easily confounded and misinterpreted as sporadic, or be due to an autosomal recessive inheritance ${ }^{4,7}$.

\section{DYSTONIA PLUS}

If it is dystonia plus, the issue is about following the symptom: myoclonus or Parkinsonism? Is there levodopa response?

\section{Myoclonus}

In myoclonus dystonia, myoclonus usually is prominent and dystonia is represented as torticollis or writer cramp. Occasionally, dystonia can be the only disorder manifestation. Symptoms respond to alcohol. There are genetic heterogeneity and two known causative loci (DYT11 and 15$)^{8}$. Gene was described only in DYT11 (sarcoglycan epsilon - SGCE) ${ }^{9}$.

\section{Parkinsonism}

If Parkinsonism is the other following symptom in dystonia plus, the questions to be answered are:

- Is there levodopa response?

- What is the inheritance?

- Was the onset sudden?

\section{Is there levodopa response?}

If dystonia respond to levodopa, dopa-responsive dystonia (DRD) is likely. There are two main genes responsible for DRD: GCH1 and TH. GCH 1 (GTP cyclohydrolase 1) is transmitted as an autosomal dominant way, with complete remission of symptoms after low doses of levodopa administration and there is a typical diurnal fluctuation (DYT5a $)^{10}$. Tyrosine hydroxylase (TH) is transmitted in an autosomal recessive fashion and is also called recessive Segawa syndrome or recessive DRD (DYT5b). There is also marked improvement with levodopa, diurnal fluctuation, and differently from dominant DRD, frequent motor and speech delay ${ }^{11}$.

\section{Inheritance is X-linked or recessive?}

In X-linked dystonia, only men will be affected in pedigree. Lugbag (Filipino dialect for twisted) occurs predominantly in families from the Philippines. Besides Parkinsonism, chorea and ballism have been described ${ }^{12}$. If dystonia Parkinsonism is recessive and unresponsive to levodopa, DYT16 should be considered. Some DYT16 patients do not have Parkinsonism and present a generalized dystonia form, with prominent speech involvement ${ }^{13}$.

\section{Was the onset sudden?}

DYT12 has a typical rapid evolution of bulbar and limb dystonia in a cranium-caudal spread with Parkinsonian features frequently without tremor and succeeding to psychological and physical triggers ${ }^{14}$. 


\section{PAROXYSMAL DYSTONIA}

Paroxysmal dyskinesias are intermittent movement disorders manifested by dystonia, chorea, and ballismus ${ }^{15}$. If paroxysmal, one should check if it is kinesigenic or nonkinesigenic.

\section{Kinesigenic}

Paroxysmal kinesigenic dystonia is characterized by brief episodes of involuntary movements induced by sudden voluntary ones. Attacks last several seconds in a daily basis (usually less than one minute), with no loss of consciousness, and with good response to antiepileptic drugs ${ }^{16}$. If kinesigenic, the questions to be answered are:

- Is there epilepsy?

- Is there spasticity or episodic ataxia?

- Are there other conditions, such as cognitive impairment or hemolytic anemia?

\section{Epilepsy}

Several patients have epilepsy as comorbidity (usually infantile benign seizures). There is genetic heterogeneity, and testing is possible for only DYT $10^{17}$.

\section{Spasticity or ataxia}

If kinesigenic and associated with spasticity, or episodic ataxia, DYT9 is probable, there is no genetic testing for this condition and in some patients there is acetazolamide response. It is clinically similar to DYT8: in both episodes, it can be triggered by alcohol, stress, and fatigue, but only in DYT9 exercise can precipitate the episodes ${ }^{18}$.

\section{Other conditions}

If paroxysmal exercise dyskinesia induced is associated with epilepsy (absence seizures in majority) and/or ataxia, mild cognitive impairment, hemolytic anemia, retyculocytosis, and hypoglycorrachia, DYT18 is possible, it can be tested and there is a chance of response to ketogenic diet ${ }^{19}$.

\section{Nonkinesigenic}

Finally, if nonkinesigenic and when precipitated by alcohol, stress, and caffeine with good response to benzodiazepines, DYT8 is likely and can be tested ${ }^{20}$. If there are no obvious triggers, DYT20 is possible, however it unfortunately cannot be tested ${ }^{21}$.

\section{References}

1. Defazio G, Abbruzzese G, Livrea P, Berardelli A. Epidemiology of primary dystonia. Lancet Neurol 2004;11:673-678.

2. Geyer HL, Bressman SB. The diagnosis of dystonia. Lancet Neurol 2006;9:780-790.

3. Bressman SB, Hunt AL, Heiman GA, et al. Exclusion of the DYT1 locus in a non-Jewish family with early-onset dystonia. Mov Disord 1994;9:626-632

4. Saunders-Pullman R, Raymond D, Senthil G, et al. Narrowing the DYT6 dystonia region and evidence for locus heterogeneity in the AmishMennonites. Am J Med Genet 2007;143:2098-2105.

5. Ahmad F, Davis MB, Waddy HM, Oley CA, Marsden CD, Harding AE. Evidence for locus heterogeneity in autosomal dominant torsion dystonia. Genomics 1993;15:9-12

6. Leube B, Rudnicki D, Ratzlaff T, Kessler KR, Benecke R, Auburger G. Idiopathic torsion dystonia: assignment of a gene to chromosome 18p in a German family with adult onset, autosomal dominant inheritance and purely focal distribution. Hum Molec Genet 1996;5:1673-1677.

7. Kostic VS, Svetel M, Kabakci K, et al. Intrafamilial phenotypic and genetic heterogeneity of dystonia. J Neurol Sci 2006;250:92-96.

8. Valente EM, Misbahuddin A, Brancati F, et al. Analysis of the epsilonsarcoglycan gene in familial and sporadic myoclonus-dystonia: evidence for genetic heterogeneity. Mov Disord 2003;18:1047-1051.

9. Zimprich A, Grabowski M, Asmus F, et al. Mutations in the gene encoding epsilon-sarcoglycan cause myoclonus-dystonia syndrome. Nat Genet 2001;29:66-69.

10. Ichinose H, Ohye T, Takahashi E, et al. Hereditary progressive dystonia with marked diurnal fluctuation caused by mutations in the GTP cyclohydrolase I gene. Nature Genet 1994;8:236-242.

11. Ludecke B, Knappskog PM, Clayton PT, et al. Recessively inherited L-DOPA-responsive parkinsonism in infancy caused by a point mutation (L205P) in the tyrosine hydroxylase gene. Hum Molec Genet 1996;5:1023-1028.

12. Makino S, Kaji R, Ando S, et al. Reduced neuron-specific expression of the TAF1 gene is associated with X-linked dystonia-parkinsonism. Am J Hum Genet 2007;80:393-406.

13. Camargos S, Scholz S, Simon-Sanchez J, et al. DYT16, a novel young onset dystonia-parkinsonism disorder: identification of a segregating mutation in the stress-response protein PRKRA. Lancet Neurol 2008;7:207-215.

14. de Carvalho Aguiar P, Sweadner KJ, Penniston JT, et al. Mutations in the $\mathrm{Na}(+) / \mathrm{K}(+)$-ATPase alpha-3 gene ATP1A3 are associated with rapid-onset dystonia parkinsonism. Neuron 2004;43:169-175.

15. Lotze T, Jankovic J. Paroxysmal kinesigenic dyskinesias. Semin Pediatr Neurol 2003;10:68-79.

16. Bruno MK, Hallett M, Gwinn-Hardy K, et al. Clinical evaluation of idiopathic paroxysmal kinesigenic dyskinesia: new diagnostic criteria. Neurology 2004;63:2280-2287.

17. Chen WJ, Lin Y, Xiong ZQ, et al. Exome sequencing identifies truncating mutations in PRRT2 that cause paroxysmal kinesigenic dyskinesia. Nat Genet 2011;43:1252-1255.

18. Muller $\mathrm{U}$, Steinberger $\mathrm{D}$, Nemeth $\mathrm{AH}$, et al. Clinical and molecular genetics of primary dystonias. Neurogenetics 1998;1:165-177.

19. Suls A, Dedeken P, Goffin K, et al. Paroxysmal exercise-induced dyskinesia and epilepsy is due to mutations in SLC2A1, encoding the glucose transporter GLUT1. Brain 2008;131:1831-1844.

20. Rainier S, Thomas D, Tokarz D, et al. Myofibrillogenesis regulator 1 gene mutations cause paroxysmal dystonic choreoathetosis. Arch Neurol 2004;61:1025-1029.

21. Spacey SD, Adams PJ, Lam PCP, et al. Genetic heterogeneity in paroxysmal nonkinesigenic dyskinesia. Neurology 2006;66:1588-1590. 